\title{
ANALISIS PERILAKU KELOMPOK DALAM ORGANISASI FORUM ANTI FITNAH DAN HOAX (FAFHH)
}

\author{
Zakaria Satrio Darmawan S.PT., M.I.Kom ${ }^{1}$, Angga Pradipta Baskoro ${ }^{2}$ \\ Universitas Budi Luhur, zsatrio@gmail.com., \\ Universitas Bina Sarana Informatika, angga.apb@ bsi.ac.id.
}

\begin{abstract}
ABSTRAKSI
Analisis ini berisi tentang perilaku dalam organisasi FAFHH (FORUM ANTI FITNAH ), dengan metode partisipasi observasi dimana peneliti tidak hanya menggunakan metode pengumpulan data atau studi pustaka namun juga ikut berpartisipasi dalam organisasi FAFHH. Metode analisis yang dipakai adalah kualitatif deskriptif. Berdasarkan hasil penelitian organisasi akan berkembang dengan baik jika hubungan antara anggota dan pimpinan dikategorikan cukup baik secara personal maupun professional kerja, hubungan personal dibangun atas dasar ketertarikan terhadap hal yang sama, secara profesional adalah deng an menjalankan tugas yang sudah diberikan dengan baik sesuai karena akan dievaluasi secara berlaka.
\end{abstract}

Kata kunci: analisis, perilaku kelompok, FAFHH

\section{ABSTRACT}

This analysis contains behavior in the FAFHH (Anti-Defamation and Hoaks Society) organization, with a participatory observation method where researchers not only use data collection methods or literature studies but also participate in FAFHH organizations. The analytical method used is descriptive qualitative. Based on the results of organizational research will develop well if the relationship between members and leaders is categorized quite both personally and professionally work, personal relationships are built on the basis of interest in the same thing, professionally is by carrying out tasks that have been given properly accordingly because it will be evaluated mere.

Keywords: analysis, group behavior, FAFHH 


\section{A. PENDAHULUAN}

Setiap manusia dalam berbagai kegiatan apapun akan terlibat dalam aktivitas kelompok. Kelompok termasuk bagian dari kehidupan organisasi. Kelompok sendiri merupakan suatu unit yang terdiri atas dua orang atau lebih yang satu sama lain berinteraksi dan menjadi kesatuan manusia yang hidup bersama yang memiliki hubungan timbal balik untuk mencapai tujuan yang telah ditetapkan secara bersama-sama dalam satu wadah tertentu dan saling bergantung satu dengan yang lainnya.

Pada umumnya manusia yang menjadi anggota dari suatu organisasi besar atau kecil sangat kuat kecenderungannya untuk mencari keakraban dalam kelompok tertentu. Dimulai dari adanya kesamaan tugas pekerjaan yang dilakukan, kedekatan tempat kerja, seringnya berjumpa, dan barang kali adanya kesamaan kesenangan (hobi) maupun adanya kesamaan tujuan para anggotanya, maka timbulah kedekatan satu sama lain. Mulailah mereka berkelompok di dalam suatu organisasi.

FAFHH adalah salah satu organisasi yang dibentuk berdasarkan kesamaan tujuan para anggotanya dimana FAFHH berpartisipasi untuk membantu mewujudkan masyarakat sipil yang aktif, damai, dan sejahtera juga berupaya memerangi tipuan dan kebencian, mengembangkan organisasi yang kuat,

kredibel, dan akuntabel, untuk memungkinkannya mencapai tujuannya hingga mengintegrasikan semua aspek sosial positif, untuk menciptakan masyarakat yang tercerahkan dan kebal terhadap wabah tipuan.

FAFHH didirikan pada tanggal 19 November 2016 dan telah mempelopori banyak inisiatif anti hoax, seperti crowdsourced hoax busting, edukasi literasi digital untuk publik, CekFakta.com, dan kampanye publik untuk meningkatkan kesadaran tentang hoax dan bahayanya, kesuksesan program yang dijalankan FAFHH tentu tidak lepas dari tanggung jawab para anggotanya baik atasan maupun bawahan.

Maka dari itu, peneliti tertarik untuk menganalisis perilaku kelompok dalam organisasi FAFHH bagaimana mereka dalam bersikap sehingga dapat terus melakukan inisiatif, Adapun rumusan masalah yang akan peneliti analisis, yaitu:
1.Bagaimana perilaku
pimpinan

FAFHH?

2.Bagaimana Perilaku Bawahan

FAFHH?

3. Bagaimana pola komunikasi kelompok dalam organisasi FAFHH

4. Apakah kelompok dalam organisasi FAFHH termasuk ke dalam karakteristik kelompok menurut Reitz?

5. Apa bentuk kelompok yang tepat untuk menggambarkan kelompok dalam organisasi FAFHH?

6. Apa saja faktor keterpaduan yang mempengaruhi organisasi FAFHH?

\section{B. LANDASAN TEORI \\ Kelompok}

Menurut Wahjono (2010) dalam Dian Anggraini Rachman dkk. Berkelompok merupakan suatu kebutuhan, dalam arti tanpa berkelompok seseorang tidak nyaman untuk hidup, bahkan mungkin tidak bisa hidup. Diantara alasan orang berkelompok adalah untuk mencapai tujuan, karena berkelompok menimbulkan kekuatan, maka tentu saja akan memudahkan pencapaian tujuan.

Menurut DeVito (1997) kelompok merupakan sekumpulan individu yang cukup kecil bagi semua anggota untuk berkomunikasi secara relatif mudah. Para anggota saling berhubungan satu sama lain dengan beberapa tujuan yang sama dan memiliki semacam organisasi atau struktur di antara mereka.

Kelompok mengembangkan norma-norma, atau peraturan yang mengidentifikasi tentang apa yang dianggap sebagai perilaku yang diinginkan bagi semua anggotanya.

\section{Perilaku Kelompok}

Perilaku merupakan suatu fungsi dari interaksi antara individu dengan lingkungannya. Sedangkan kelompok merupakan dua individu atau lebih yang berinteraksi dan saling bergantung, bergabung untuk mencapai sasaran tertentu. (Robbins, 2003)

Menurut Khoiriyah (2016), perilaku kelompok adalah aktivitas yang dapat diamati dari dua atau lebih manusia atau individu yang berinteraksi dan berkumpul untuk mencapai tujuan tertentu. 
Menurut Bahtiar (2016), perilaku kelompok adalah suatu aktivitas yang dilakukan oleh seorang individu dengan yang lainnya untuk mendapatkan aspirasi anggota, berinteraksi dari setiap individu dan saling bergabung untuk mencapai sasaran yang diinginkan.

\section{Pola Komunikasi Kelompok}

Pola komunikasi menurut Effendy, 1986 Pola Komunikasi adalah proses yang dirancang untuk mewakili kenyataan keterkaitannya unsur-unsur yang dicakup

beserta keberlangsungannya, guna memudahkan pemikiran secara sistematik dan logis.Komunikasi adalah salah satu bagian dari hubungan antar manusia baik individu maupun kelompok dalam kehidupan seharihari (Effendy, 1986) dari pengertian ini jelas bahwa Komunikasi melibatkan sejumlah orang dimana seorang menyatakan sesuatu kepada orang lain, jadi yang terlibat dalam Komunikasi itu adalah manusia itu. Pola komunikasi dibagi menjadi tiga yaitu,komunikasi satu arah, komunikasi dua arah dan komunikasi multi arah. Menurut Effendy, 1989:32

Pola Komunikasi terdiri atas 3 macam yaitu:

1. Pola komunikasi satu arah adalah proses penyampaian pesan dari Komunikator kepada Komunikan baik menggunakan media maupun tanpa media, tanpa ada umpan balik dari Komunikan dalam hal ini Komunikan bertindak sebagai pendengar saja.

2. Pola komunikasi dua arah atau timbal balik (Two way traffic communication) yaitu Komunikator dan Komunikan menjadi saling tukar fungsi dalam menjalani fungsi mereka, Komunikator pada tahap pertama menjadi komunikan dan pada tahap berikutnya saling bergantian fungsi. Namun pada hakikatnya yang memulai percakapan adalah komunikator utama, komunikator utama mempunyai tujuan tertentu melalui proses Komunikasi tersebut, Prosesnya dialogis, serta umpan balik terjadi secara langsung. (Siahaan, 1991)

3. Pola komunikasi multi arah yaitu Proses komunikasi terjadi dalam satu kelompok yang lebih banyak di mana Komunikator dan Komunikan akan saling bertukar pikiran secara dialogis.

\section{Karakteristik Kelompok}

Rakhmat (2007) dalam Saleh (2015) berpendapat bahwa karakteristik kelompok meliputi ukuran kelompok, jaringan

kelompok, kohesi kelompok dan kepemimpinan. Faktor lain yang mempengaruhi hubungan antara prestasi dan ukuran kelompok adalah tujuan kelompok.

Menurut Reitz (1977) kelompok mempunyai karakteristik sebagai berikut:

1. Terdiri dari dua orang atau lebih

2. Berinteraksi satu sama lain

3. Saling membagi beberapa tujuan yang sama

4. Melihat dirinya sebagai suatu kelompok

Karakteristik atau ciri suatu Kelompok menurut Shaw (1979) ada enam, yaitu:

1. Persepsi dan kognisi anggota kelompok.

2. Motivasi dan kebutuhan kepuasan (need satisfaction)

3. Tujuan kelompok (Group Goals)

4. Organisasi Kelompok

5. Ada ketergantungan antara anggota kelompok

6. Interaksi

\section{Bentuk Kelompok}

Bentuk kelompok menurut Thoha (2014), yaitu:

1. Kelompok Primer

Kelompok primer adalah kelompok

yang disifati dengan adanya keakraban, kerjasama dan hubungan tatap muka dan merupakan, dasar dalam pembentukan sifat sosial dan cita-cita individu.

2. Kelompok Formal dan Informal

Kelompok formal adalah suatu kelompok yang sengaja dibentuk untuk melaksanakan suatu tugas

tertentu. Anggotanya biasanya diangkat oleh organisasi. Sejumlah

orang yang ditetapkan untuk melaksanakan suatu tugas tertentu merupakan bentuk dari kelompok formal. Contoh dari kelompok formal ini di antaranya komite atau panitia, unit-unit kerja tertentu seperti bagian laboratorium riset dan pengembangan, tim manajer, dan lain sebagainya. 
Sedangkan kelompok informal adalah suatu kelompok yang tumbuh dari proses interaksi, daya tarik dan kebutuhan kebutuhan seseorang. Anggota kelompok tidak diatur dan diangkat, keanggotaan ditentukan oleh daya tarik bersama dari individu dan kelompok.

Kelompok informal ini sering timbul berkembang dalam kelompok formal, karena adanya beberapa anggota secara tertentu mempunyai nilai-nilai yang sama yang perlu ditularkan (shared) sesama anggota lainnya.

3. Kelompok Terbuka dan Tertutup

Kelompok terbuka adalah suatu kelompok yang mempunyai rasa

tanggapakanperubahandan

pembaharuan. Sedangkan kelompok tertutup adalah kecil

kemungkinannya menerima perubahan dan pembaharuan, atau mempunyai kecenderungan tetap menjaga

kestabilan.

\section{Kelompok Referensi}

Suatu kecenderungan yang positif dari perilaku manusia ini adalah adanya usaha untuk mencari umpan balik (feedback) tentang dirinya. Sehingga manusia berkeinginan untuk menilai dirinya, apakah di dalam menjalankan tugas pekerjaan berhasil atau tidak. Kelompok referensi ini adalah setiap kelompok dimana seseorang melakukan referensi atasnya. Orang

ini mempergunakan kelompok tersebut sebagai suatu ukuran (standar) untuk evaluasi dirinya dan sebagai sumber dari nilai juga sikap pribadinya.

Kelompok ini dapat dikatakan memberikan dua fungsi bagi seseorang untuk evaluasi diri. Jika ditinjau dari besaran jumlah anggota, maka dikenal dua jenis kelompok yaitu kelompok kecil (small group) dan kelompok besar (large group).

Menurut Haren (1962) dalam Saleh (2015), suatu kelompok dapat digolongkan ke dalam bentuk kelompok kecil apabila ukurannya mulai dari dua orang sampai dengan 20 orang.
Infante et al. (2003) dan DeVito (2002), menetapkan batas maksimal sebesar 15 orang. Alasannya adalah ketika suatu kelompok beranggotakan lebih dari 15 orang, maka akan semakin sulit untuk kelompok tersebut bertukar informasi. Jumlah idealnya adalah antara tujuh hingga sepuluh orang. Makin besar jumlahnya maka makin renggang hubungan orang-orang di dalam kelompok. Sebaliknya, kalau terlalu kecil maka pandangan dalam diskusi sangat terbatas, demikian juga masalah dana yang diperlukan.

Bentuk kedua dari jenis kelompok ditinjau dari ukuran kelompok adalah kelompok besar (large group), yang bercirikan ukuran anggota kelompok di atas 20 orang sampai dengan 30 orang. Kelompok yang memiliki jumlah anggota lebih dari jumlah tersebut ada baiknya dipecah dalam dua kelompok, tetapi dipayungi dalam groups association (asosiasi kelompok atau gabungan kelompok).

\section{Perilaku Pemimpin}

Menurut Mulyasa yang dikutip oleh Nur Efendi (2015) dalam Basri (2018), perilaku kepemimpinan ada tiga dimensi, yang didasarkan pada hubungan antara tiga faktor, yaitu perilaku tugas (Task behavior), perilaku hubungan (relationship behavior) dan kematangan (maturity). Perilaku tugas merupakan pemberian petunjuk oleh pemimpin terhadap anak buah meliputi penjelasan tertentu, apa yang harus dikerjakan, bilamana, dan

bagaimana mengerjakannya, serta mengawasi mereka secara ketat. Perilaku hubungan merupakan ajaran yang disampaikan oleh pemimpin melalui komunikasi dua arah yang meliputi mendengar dan melibatkan anak buah dalam pemecahan masalah. Adapun kematangan adalah kemampuan dan kemauan anak buah dalam mempertanggungjawabkan pelaksanaan tugas yang dibebankan kepada pimpinan.

Menurut Rivai (2004) kepemimpinan (leadership) adalah proses mempengaruhi atau memberi contoh kepada pengikut-pengikutnya lewat proses komunikasi dalam upaya mencapai tujuan organisasi. Keseluruhan tindakan guna mempengaruhi serta menggiatkan orang dalam usaha bersama untuk mencapai tujuan, atau dengan definisi 
yang lebih lengkap dapat dikatakan bahwa kepemimpinan adalah proses pemberian jalan yang mudah dari pada pekerjaan orang lain yang terorganisir dalam organisasi formal guna mencapai tujuan yang telah ditetapkan.

\section{Perilaku Bawahan}

Menurut Saputra (2008) Perilaku seorang pemimpin memiliki banyak pengaruh pada organisasi terutama pada bawahan, Hal ini diyakini berdampak memperbesar hasil kerja, serta hal ini disebabkan karena bawahan merasa percaya kepada pemimpinnya sehingga bawahan memiliki motivasi untuk bekerja lebih daripada apa yang diharapkan organisasi.

Pengaruh pemimpin tidak terlepas dari kualitas hubungan antara pimpinan dengan bawahan tetapi dipengaruhi oleh beberapa faktor. Berikut adalah faktor-faktor yang mempengaruhi kualitas hubungan tersebut:

\section{Kesamaan dan Rasa Suka}

Ashkanasy and O'Connor (1997) mengemukakan adanya tahapan awal timbulnya hubungan atasan-bawahan. Pada tahapan awal ini, baik pemimpin maupun bawahan bereaksi atas impresi awal tentang karakteristik personal dan demografi masingmasing. Pada tahap ini, akan terjadi perasaan cocok atau tidak cocok satu sama lain. Kualitas hubungan antara atasan dan bawahan bisa menjadi tinggi dikarenakan adanya rasa tertarik (suka) dan cocok terhadap karakteristik personal maupun demografi masing-masing. Sebaliknya, kualitas hubungan atasan-bawahan bisa menjadi rendah karena adanya ketidak cocokan dalam memandang karakteristik personal dan demografi masing-masing.

Selain kemiripan karakteristik personal dan demografi, nilai, cara kerja, dan cara memandang/menyelesaikan masalah juga menimbulkan perasaan suka atau tidak suka antara atasan dan bawahan. Atasan dan bawahan yang memiliki kesamaan dalam hal nilai, cara kerja dan cara memandang atau menyelesaikan masalah memiliki potensi untuk memperoleh hubungan timbal balik dengan kualitas tinggi (Lord dan Angel 1997; Ashkanasy and O’Connor 1997).

\section{Harapan}

Harapan seorang atasan pada bawahan akan berpengaruh pada cara atasan tersebut memperlakukan bawahannya. Misalnya, seorang atasan yang menaruh harapan tinggi pada seorang bawahannya akan memberikan tugas-tugas yang menantang, memberikan pelatihan, feedback, dan sebagainya, pada bawahan tersebut.

Sebaliknya, atasan yang hanya memiliki pengharapan minimal pada bawahannya akan cenderung memberikan tugas-tugas yang sifatnya tidak penting, rutin, dengan kesempatan pelatihan dan feedback yang lebih sedikit (Wayne, Shore dan Liden, 1997).

Harapan seorang atasan juga berpengaruh pada persepsi mereka atas bawahan. Seorang atasan yang memiliki ekspektasi tinggi pada bawahannya cenderung untuk memberikan internal atribusi pada keberhasilan bawahan dan menganggap kegagalan bawahan dikarenakan faktor-faktor eksternal; demikian sebaliknya ketika seorang atasan memiliki harapan yang rendah pada bawahannya, akan menganggap kegagalan bawahan karena

persoalan kemampuan (Heneman, Greenberger dan Anonyuo, 1989 dalam Wayne, Shore dan Lyden, 1997).

\section{Kinerja}

Ashkanasy and O'Connor (1997) mengemukakan adanya tahapan lanjutan setelah impresi awal tentang karakteristik personal dan demografi masing-masing. Tahapan lanjutan ini adalah tahap pembentukan kepercayaan dari atasan dan bawahan, dimulai dengan proses penilaian kinerja dari atasan pada bawahannya.

\section{Metode Penelitian}

\section{Metode Penelitian Kualitatif}

Jenis penelitian yang digunakan adalah metode studi kasus yang sesuai disampaikan oleh Robert K Yin (2008). Studi kasus digunakan sebagai suatu penjelasan komprehensif yang berkaitan dengan berbagai aspek seseorang, kelompok, organisasi, suatu program, atau suatu situasi kemasyarakatan yang diteliti, untuk diupayakan dan ditelaah sedalam mungkin. Studi kasus juga memiliki pengertian berkaitan dengan penelitian yang terperinci tentang seseorang atau suatu unit sosial dalam kurun waktu tertentu. 
Menurut Sugiyono (2011), metode penelitian kualitatif adalah metode penelitian yang berlandaskan pada filsafat postpositivisme, digunakan untuk meneliti pada kondisi obyek yang alamiah, (sebagai lawannya eksperimen) dimana peneliti

adalah sebagai instrumen kunci, pengambilan sampel sumber data dilakukan secara purposive dan snowball, teknik pengumpulan dengan triangulasi (gabungan), analisis data bersifat induktif atau kualitatif, dan hasil penelitian kualitatif lebih menekankan makna daripada generalisasi.

Menurut Moleong (2010), penelitian kualitatif adalah penelitian yang bermaksud untuk memahami fenomena tentang apa yang dipahami oleh subyek penelitian, misalnya perilaku, persepsi, motivasi, tindakan, secara holistik dan dengan cara deskripsi dalam bentuk kata-kata dan bahasa, pada suatu konteks khusus yang alami dan dengan memanfaatkan berbagai metode ilmiah.

\section{Metode Pengumpulan Data Observasi}

Menurut Arikunto (2006), observasi adalah mengumpulkan data atau keterangan yang harus dijalankan dengan melakukan usahausaha pengamatan secara langsung ke tempat yang akan diselidiki.

Sedangkan menurut Yusuf (2017), salah satu teknik yang dapat digunakan untuk mengetahui atau menyelidiki tingkah laku nonverbal yakni dengan menggunakan teknik observasi. Apabila kita mengacu pada fungsi pengamat dalam kelompok kegiatan, maka observasi dapat dibedakan dalam dua bentuk, yaitu:

1. Participant Observer, yaitu suatu bentuk observasi dimana pengamat (observer) secara teratur berpartisipasi dan terlibat dalam kegiatan yang diamati. Dalam hal ini pengamat mempunyai fungsi ganda, yakni sebagai peneliti yang tidak diketahui dan dirasakan oleh anggota lain, dan kedua sebagai anggota kelompok peneliti berperan aktif sesuai tugas yang dipercayakan kepadanya.

2. Non-Participant Observer, yaitu suatu bentuk observasi dimana pengamat (peneliti) tidak terlibat langsung dalam kegiatan kelompok, atau dapat juga dikatakan pengamat tidak ikut serta dalam keadaan kegiatan yang diamatinya.

\section{Kepustakaan}

Menurut Mardalis (1999) dalam Mirzaqon (2017) Studi kepustakaan merupakan suatu studi yang digunakan dalam mengumpulkan informasi dan data dengan bantuan berbagai macam material yang ada di perpustakaan seperti dokumen, buku, majalah, kisah-kisah sejarah, dsb.

Studi pustaka, menurut Nazir (2013) teknik pengumpulan data dengan mengadakan studi penelaah terhadap buku-buku, literatur, catatan-catatan, dan laporan yang ada hubungannya dengan masalah

yang dipecahkan. Teknik ini digunakan untuk memperoleh dasar-dasar dan pendapat secara tertulis yang dilakukan dengan cara mempelajari berbagai literatur yang berhubungan dengan masalah yang diteliti. Hal ini juga dilakukan untuk mendapatkan data sekunder yang akan digunakan sebagai landasan perbandingan antara teori dengan prakteknya di lapangan. Data sekunder melalui metode ini diperoleh dengan browsing di internet, membaca berbagai literatur, hasil kajian dari peneliti terdahulu, catatan perkuliahan, serta sumber-sumber lain yang relevan. (Ainin, 2017).

Sedangkan menurut Sugiyono, studi kepustakaan berkaitan dengan kajian teoritis dan referensi lain yang berkaitan dengan nilai, budaya dan norma yang berkembang pada situasi sosial yang diteliti, selain itu studi kepustakaan sangat penting dalam melakukan penelitian, hal ini dikarenakan penelitian tidak akan lepas dari literatur-literatur ilmiah. (Sugiyono, 2012).

\section{Metode Analisis \\ Studi Kasus}

Studi kasus menurut Yin (2008) dalam Asmara (2013) adalah suatu inkuiri empiris yang menyelidiki fenomena dalam konteks kehidupan nyata, bilamana batas-batas antar fenomena dan konteks tak tampak dengan tegas dan dimana: multi sumber bukti dimanfaatkan. Sebagai suatu inquiry studi 
kasus tidak harus dilakukan dalam waktu yang lama dan tidak pula harus tergantung pada data etnografi atau observasi partisipan. Bahkan menurut Yin seorang peneliti bisa saja melakukan studi kasus yang valid dan berkualitas tinggi

tanpa meninggalkan kepustakaan, tergantung pada topikyang akan diselidiki.

Sedangkan menurut Bogdan (1980) studi kasus adalah kajian rinci atas suatu latar atau satu orang subjek atau satu tempat penyimpanan dokumen. Pelaksanaan studi kasus ini bersifat fokus, di mana pengambilan data dan kegiatan penelitian menyempit ke tempat penelitian, subjek, bahan, topik dan tema. Selanjutnya Bogdan menjelaskan bahwa untuk penelitian sekolah yang cocok untuk digunakan adalah jenis studi kasus observasi. Dalam studi kasus jenis ini teknik pengumpulan data yang utama

adalah melalui observasi pelibatan (participant observation), dan focus studinya adalah suatu organisasi tertentu yang bisa terdiri dari;

1. Suatu tempat tertentu di dalam organisasi

2. Suatu kelompok khusus orang, dan

3. Kegiatan sekolah (Bogdan.1980:74).

\section{PEMBAHASAN}

\section{Perilaku Pemimpin}

Perilaku Pemimpin FAFHH sesuai dengan kutipan teori Nur Efendi (2015) dan juga Rivai (2004), dimana perilaku pimpinan FAFHH, selalu menjelasakn secara detail maupun spesifik mengenai pekerjaan, kegiatan ataupun program yang sedang dilaksanakan maupun yang sedang direncanakan. Tidak hanya memberikan

penjelasan terkait pekerjaan yang diberikan, pimpinan MAFINO juga memberikan perhatian atau pengawasan ketat selama anggotanya mengerjakan pekerjaanya melaluo report wajib dari setiap pekerjaan yang dibebankan kepada anggota organisasi FAFHH. Melalui report ini juga pimpinan dan anggota FAFHH berusaha berkomunikasi. Melalui proses komunikasi dua arah ini pula pimpinan berusaha memberikan

arahan dan pengaruhnya guna terlaksanakannya rencana sesuai dengan tujuan yang ingin dicapai organisasi

FAFHH.

\section{Perilaku Anggota}

Bebeberapa faktor yang mempengaruhi kualitas hubungan antara anggota dan pimpinan:

\section{Kesamaan dan rasa suka}

Anggota dan pimpinan FAFHH memiliki ketertarikan yang sama dalam beberapa hal sehingga satu sama lain dapat membangun hubungan personal dikatakan cukup baik. Dengan hubungan personal baik bepengaruh pada cara kerja dan pandangan dalam menyelesaikan suatu masalah tersebut dapat hingga memperoleh hasil yang baik karena menciptakan hubungan timbal baik yang tinggi satu sama lain. Tahap pertama ini anggota FAFHH mempunyai hubungan antara pimpinan dengan bawahan berupa kesamaan ilmu pengetahuan dan cara berfikir kritis dalam menyelsaikan suatu masalah yang ada.

\section{Harapan}

Dalam menciptakan hubungan timbal balik yang baik antara pimpinan dan

anggotanya, FAFHH selalu memberikan tugas harian rutin dan beberapa tambahan tugas lainnya yang dibagikan sesuai jobdesc anggotanya. Tugas rutin harian seperti melakukan pemeriksaan fakta yang kemudian akan diupload pada sosial media FAFHH, tugas lainnya yaitu membantu menjalankan program organisasi yang sedang berlangsung seperti membuat iklan layanan masyarakat di youtube, membuat public campaign, workshop dan pelatihan literasi digital kepada masyarakat.

\section{Kinerja}

Setelah terjalinnya hubungan personal yang baik antara pimpinan dan anggota, disertai dengan ekspetasi pimpinan terhadap anggotanya yang tinggi dan membuat beberapa tugas yang harus dikerjakan oleh anggota yang sudah dibagikan sesuai jobdesc masing-masing. FAFHH memberikan standar KPI (key performance indeks) pada tiap anggota sehingga pimpinan megetahui apa yang sedang dikerjakan atau sudah dilakukan oleh anggota dan sebagai bahan evaluasi kedepannya agar organisasi semakin berkembang.

\section{Pola Komunikasi FAFHH}

Berdasarkan hasil analisis, pola komunikasi berdasarkan Effendy Effendy, 1989:32 yang 
dilakukan oleh pimpinan dan anggota FAFHH pola komunikasi dua arah atau timbal balik (Two way traffic communication) yaitu pimpinan sebagai komunikator (pengirim pesan) dan anggota merupakan komunikan (penerima pesan).

Pimpinan memulai percakapan yang memiliki tujuan untuk dibicarakan kepada anggotanya yang kemudian terjadi umpan balik langsung, dalam pola komunikasi ini pimpinan dan anggota menjadi saling tukar fungsi dalam menjalani fungsi mereka, Komunikator pada tahap pertama menjadi komunikan dan pada tahap berikutnya saling bergantian fungsi.

\section{Karakteristik Kelompok}

Menurut Reitz (1977) kelompok mempunyai karakteristik sebagai berikut:

1. Terdiri dari dua orang atau lebih

2. Berinteraksi satu sama lain

3. Saling membagi beberapa tujuan yang sama.

4. Melihat dirinya sebagai suatu kelompok

Jika penulis lihat dari Organisasi FAFHH sudah sesuai karakterisktik kelompok menurut Reitz, yaitu:

1. Kelompok FAFHH beranggotakan 80 orang, yang mana menurut Reitz, kelompok itu beranggotakan minimal 2 orang. Dalam hal ini syarat karakteristik kelompok pertama sudah dipenuhi oleh FAFHH.

2. Anggota kelompok dalam FAFHH sekalikali bertemu, bercakap-cakap dan mengerjakan sesuatu bersama-sama sesuai. Yang dalam hal ini sesuai dengan karakteristik kelompok kedua.

3. Anggota-anggota kelompok mempunyai kesamaan. Yang mana kesamaan pada anggota FAFHH salah satunya adalah keresahan terkait banyaknya informasi palsu yang beredar di masyarakat. Apapun dasarnya, suatu kelompok memiliki sesuatu yang sama adalah salah satu ciri mengidentifikasikan suatu kelompok sesuai dengan point ketiga Reitz.

4. Karakteristik keempat dapat dilihat melalui poin kedua dan ketiga dimana orang-orang yang berinteraksi satu sama lain dan membagi tujuan yang sama atau. Para anggota FAFHH telah terima dari proses interaksi dan kesamaan inilah yang akan membimbing mereka untuk mengenali dan memahami dirinya merupakan bagian dari kelompok FAFHH.

\section{Bentuk Kelompok}

Banyak terdapat beberapa bentuk kelompok. Teori- teori yang mencoba melihat asal mula terbentuknya kelompok seperti diuraikan diatas menyatakan betapa banyaknya pola bentuk kelompok tersebut. Sosiolog dan psikolog yang mempelajari perilaku sosial dari orang-orang didalam organisasi. Mengidentifikasikan beberapa perbedaan tipe suatu kelompok dari

perbedaan dan banyaknya bentuk kelompok, FAFHH termasuk kedalam beberapa bentuk kelompok diantaranya.

\section{Kelompok Formal}

Kelompok formal adalah suatu kelompok yang sengaja dibentuk untuk melaksanakan tugas tertentu. Pada FAFHH sendiri kelompok formal adalah fact-checker yang dipilih langsung organisasi atau office FAFHH dan bertugas memeriksa fakta yang beredar di masyarakat kemudian turut serta bertanggung jawab dalam melaksanakan kegiatan-kegiatan yang dibuat oleh FAFHH yang kemudian akan dibantu oleh relawan FAFHH.

\section{Kelompok Informal}

Adapun kelompok informal suatu kelompok yang tumbuh dari proses interaksi, daya tarik, dan kebutuhan-kebutuhan seseorang. Kelompok informal FAFHH sendiri adalah relawan yang tergabung yang memiliki daya tarik dan tujuan yang sama dengan visi misi FAFHH yang turut serta membantu segala kegiatan FAFHH secara sukarela dan juga menjadi kader anti hoaks di masyarakat secara langsung.

\section{Faktor Keterpaduan}

Ada beberapa faktor keterpaduan yang dapat mempengaruhi kelompok, yaitu sebagai berikut:

\section{Kesamaan nilai dan tujuan}

FAFHH memiliki kesamaan nilai dan tujuan terlihat dari membuat kegiatan yang dilakukan secara bersama dan memiliki tujuan yang sama yaitu memerangi hoax dan hate speech yang beredar di masyarakat baik secara online maupun offline seperti melakukan cek fakta melalui daring dan membuat seminar maupun 
kampanye publik secara langsung untuk mengedukasi masyarakat.

\section{Keberhasilan dalam mencapai tujuan}

Keberhasilan untuk mencapai tujuan yang dilakukan FAFHH sesuai dengan visinya yaitu membuat masyarakat berpikir kritis dalam menerima informasi yang beredar, menggencarkan literasi digital, masyarakat turut serta dan aktif untuk menyebarkan klarifikasi hoax yang beredar agar menciptakan masyarakat yang aktif, damai dan makmur.

\section{Status atau citra kelompok}

FAFHH adalah organisasi anti-hoax CSO (Civil Society Organization) yang bergerak untuk mengatasi persebaran

berita atau informasi fitnah, hasud/provokasi dan hoax di masyarakat. Berdiri sejak 19 November 2016, FAFHH telah melakukan beberapa kegiatan untuk melawan hoaks, Mulai dari inisiatif cek fakta yang sudah bersertifikasi

IFCN (International Fact-Checking Network, edukasi masyarakat, hingga kampanye publik anti hoaks.

\section{Penyelesaian perbedaan}

Cara penyelesaian perbedaan pendapat dalam FAFHH dengan cara membuat beberapa pilihan untuk penyelesaiannya

kemudian semua kelompok bermusyawarah untuk memilih sesuai dengan yang diinginkan dan pilihan terbanyak lah yang akan dipilih sesuai dengan persetujuan dan kesepakatan bersama diakhir.

\section{Kecocokan terhadap norma-norma}

FAFHH melakukan kegiatan sesuai dengan $\mathrm{AD} / A R T$ yang telah tercatat sejak awal FAFHH didirikan dan setiap

kegiatan FAFHH dapat dalam dipertanggungjawabkan kepada publik.

\section{Daya tarik pribadi}

FAFHH memiliki banyak relawan yang tersebar di seluruh Indonesia sehingga mudah untuk menjangkau seluruh lapisan masyarakat dari berbagai daerah.

\section{Persaingan antar kelompok}

Yang menjadi pesaing FAFHH saat ini adalah media online periksa fakta, karena keterbatasan tools FAFHH yang menjadikan sulitnya memeriksa fakta dengan cepat dibandingkan media online periksa fakta lainnya.

\section{PENUTUP}

Berdasarkan hasil penelitian dan pembahasan sebelumnya, maka penulis

dapat menarik kesimpulan yang merupakan jawaban dari rumusan masalah penelitian sebagai berikut:

1. Perilaku pemimpin berperan sebagai kunci utama dalam berorganisasi di FAFHH karena bertanggung jawab sebagai mediator untuk organisasi dan kelompok di dalamnya untuk memberikan saran, kritik, dan ide.

2. Perilaku anggota FAFHH adalah berperan aktif pada setiap tugas yang diberikan oleh pimpinan berpengaruh signifikan terhadap keberhasilan kegiatan-kegiatan yang dilakukan

FAFHH dan bagaimana dampaknya di masyarakat.

3. Pola komunikasi pada FAFHH berperan sebagai ujung tombak

dimana komunikasi harus dikedepankan untuk meningkatkan kinerja kelompok yang ada di dalam

organisasi tersebut hingga berkolaborasi untuk mencapai tujuan bersama. Pola komunikasi yang digunakan adalah bersifat formal karena sudah adanya prosedur yang terkait dengan jabatan, mereka berdiskusi dalam ruang lingkup sebagai teman kerja, agar mampu menciptakan suatu komunikasi yang kondusif, yaitu dengan mengadakan acara ataupun kegiatan-kegiatan eksternal dan internal.

4. Karakteristik kelompok menurut Reitz pada FAFHH yaitu memiliki lebih dari dua orang anggota yang saling berinteraksi dan memiliki tujuan yang sama.

5. Bentuk kelompok FAFHH terdiri dari formal dan informal. Kelompok formal adalah tim office yang mengelola secara teknis maupun non-teknis semua kegiatan yang akan dilakukan oleh FAFHH, dan kelompok informal terdiri dari gabungan masyarakat yang turut aktif menjadi relawan FAFHH di seluruh Indonesia. 
6. Faktor keterpaduan FAFHH adalah memiliki kesamaan nilai dan tujuan sehingga saling berkolaborasi untuk mencapai tujuan yang sama sesuai dengan AD/ART yang telah ditetapkan.

\section{Referensi}

Ainin. Q. 2017. “Metode Penelitian”. Diakses pada tanggal 10/05/2020 http://repository.unpas.ac.id/30689/ 5/BAB\%20III.pdf.

Arikunto. 2006. "Metode Penelitian". Diakses pada tanggal 10/05/2020 http://repository.unpas.ac.id/.

Azeharie, Suzy. 2015. Pola Komunikasi Antara Pedagang dan Pembeli Di Desa Pare, Kampung Inggris Kediri. Jurnal Komunikasi Universitas tarumanagar 7(2), hlm. 137-151

Basri 2008, "Perilaku Kepemimpinan Kepala Madrasah Dalam Meningkatkan Mutu Madrasah". Diakses pada 05/05/20 http://repo.iaintulungagung.ac.id/7131/

Budiman. B. 2015. "Pengaruh Kualitas Hubungan Antara AtasanBawahan Terhadap Perilaku Kerja Kontraproduktif Studi Pada Perawat Rumah Sakit Khusus Mata Palembang". Diakses pada 01/05/2020.

http://jurnal.radenfatah.ac.id/index. php/psikis/article/view/566

Devito, Joseph. $1997 . \quad$ Komunikasi Antarmanusia. Professional Books: Jakarta.

Efendi. 2015, Islamic Educational Leadership, Yogyakarta: KALIMEDIA.

Johnson, W, David, dan Johnson, P. Frank. 2012. Dinamika kelompok: Teori dan Keterampilan. Jakarta: PT. Indeks.

Mardalis. 1999. Metode Penelitian Suatu Pendekatan Propasal, Jakarta: Bumi Aksara

Mirzaqon, Abdi. 2017." Studi Kepustakaan Mengenai Landasan Teori Dan Praktik Konseling Expressive Writing". Diakses pada tanggal 10/05/2020 https://media.neliti.com/media/publ ications/253525-studi-kepustakaanmengenai-landasan-teor-c084d5fa.pdf
Moleong. 2010. "Metode Penelitian".

Diakses pada tanggal 10/05/2020 file:///C:/Users/YENE/Downloads/ $\underline{\text { S SOS } 1001285 \text { chapter3.pdf }}$

Nazir, Moh. 2013."Metode Penelitian”. Bogor: Galia Indonesia. Diakses

$$
\begin{aligned}
& \text { pada tanggal 10/05/2020 } \\
& \text { http://repository.unpas.ac.id/12356/ } \\
& \text { 6/daftar\%20 pustaka.pdf }
\end{aligned}
$$

Rachman, D. 2013. “Analisis Pengaruh Perilaku Kelompok Terhadap Kepuasan Kerja Perawat Di Rsud Syekh Yusuf Kabupaten Gowa."

Diakses pada 05/05/2020. http://digilib.unhas.ac.id/uploaded files/temporary/DigitalCollection/Z mY0NWQyYjJiODY3NzdlMDBk M2FkMjE4YTdmZWEyN2M2MD Q0NmJkNw==.pdf

Reitz H Joseph and Jewell Linda N. 1981. Group Effectiveness in Organizations. Universitas Michigan: Scott Foresman.

Reitz, Joseph H. 1977. Behavior in Organization. Ricard D, Iwin. Homewood Illinois.

Saleh. A. 2015. "Pengertian, Batasan,dan Bentuk Kelompok". Diakses pada tanggal 09/05/2020 http://repository.ut.ac.id/4463/1/LU HT4329-M1.pdf.

Saputra. 2008. "Pengaruh Perilaku Pemimpin Terhadap Kinerja Karyawan Pada Karyawan Non Manajemen Di Cv. Adi Guna Karya Surabaya." Diakses pada tanggal 04/05/2020. http://repository.unair.ac.id/7310/

Shaw, M. E. 1979. Group Dynamic: The Psychology of Small Group Behaviour. Tata McGraw-Hil Publishing Company Ltd., New Delhi.

Stephen P. Robbins. 2003. Perilaku Organisasi jilid 1, alih bahasa. Jakarta: PT. Indeks kelompok Gramedia.

Sugiyono. 2012. "Metode Penelitian". 
Diakes pada tanggal 10/05/2020

http://digilib.unila.ac.id/

Thoha, M. 2014. Perilaku Organisasi Konsep Dasar dan Aplikasinya. Jakarta: Raja Grafindo Persada.

Yin,K Robert. 2008. Case Study Research: Design and Methods Sage Publications.Inc.

Yuliani. 2016. "Pengaruh Perilaku Organisasi Terhadap Kinerja Pegawai Di Dinas Tenaga Kerja Kabupaten Bandung". Diakses pada tanggal 08/05/2020. http://repository.unpas.ac.id/9909/4 /BAB\%20II.pdf

Yusuf, Muri. 2017."Metode Penelitian”. Diakses pada tanggal 10/05/2020 file:///C:/Users/YENE/Downloads/ BAB\%20III\%20(3).pdf

Asmara. 2013. "Pengembangan Keterampilan Sosial Bagi Calon Guru". Diakses pada tanggal 13/05/2020.

http://repository.upi.edu/4526/

\section{Biodata Penulis}

Penulis 1 : Zakaria Satrio Darmawan S.PT., M.I.Kom. Saya seorang dosen di Universitas Budiluhur, saya mengajar sejak 2012, di fakultas Ilmu Komunikasi, jurusan Broadcast Jurnalism.

Saya juga kerja freelance di CV ORBIT bagian teknisi.

Penulis 2 : Angga Pradipta Baskoro. Jakarta 15 April 1989. Tahun 2010 lulus dari Program Diploma Tiga (DIII) Program Studi Periklanan AKOM BSI Jakarta. Tahun 2013 lulus dari Program Strata Satu (S1) Ilmu Komunikasi. Tahun 2016 Lulus dari Program Pasca Sarjana (S2) Magister Manajemen Universitas Bina Sarana Informatika Bandung. 